Beyond Philology No. 17/1, 2020

ISSN 1732-1220, eISSN 2451-1498

https://doi.org/10.26881/bp.2020.1.06

\title{
A non-pragmatic view on education
}

RYSZARD WENZEL

Received 10.05.2020,

received in revised form 10.07.2020,

accepted 14.07.2020.

\begin{abstract}
The point of this essay is to argue that education may improve its quality if its fundamental principles transcend the pragmatic targets, e.g. preparing the offspring to adult life, the psychosocial needs, manual, intellectual and vocational skills, etc, and deal with such essential problems as the sense of life, the nature of the world, the phenomenon of consciousness and its evolution, i.e. problems which typically become the subject of philosophical speculations and deliberations. The point of departure of the argument is the classical view that education should be seen as educing the potential of every individual learner. The possibility of such a qualitative improvement may result from the capacity of consciousness to generate complex motivational drives of learning which are rooted in the higher mental processes.
\end{abstract}

\section{Key words}

genuine interaction, cognitive appeal, higher mental processes, cognitive structure, educational domains of cognition, creation and coexistence, motivational drives of learning 


\title{
Ponad pragmatyczne spojrzenie na edukacje
}

\begin{abstract}
Abstrakt
Tematem eseju jest przekonanie, że jakość edukacji można udoskonalić jeśli jej podstawowe zasady wykrocza ponad pragmatyczne cele, takie jak przygotowywanie do dorosłego życia, psychospołeczne potrzeby, fizyczne, intelektualne i zawodowe sprawności, i obejmą swoim zakresem tak podstawowe problemy jak sens życia, natura świata, zjawisko świadomości i jego ewolucja, czyli problemy które typowo sa przedmiotem filozoficznych spekulacji i rozważań. Punktem wyjścia do tej argumentacji jest klasyczne rozumienie edukacji jako poszukiwania potencjału każdego indywidualnego ucznia. Możliwość takiego jakościowego udoskonalenia wynika $z$ działania świadomości, która generuje złożone procesy motywacyjne zakorzenione w wyższych procesach umysłowych.
\end{abstract}

\section{Slowa kluczowe}

Autentyczna interakcja, emocjonalne zaangażowanie poznawcze, wyższe procesy umysłowe, kognitywna struktura umysłu, edukacyjne pola poznania, twórczości i współistnienia, motywacja uczenia się

\section{Educational questions and expectations}

Most generally, education is expected to help people in their attempts to discover their own nature and the nature of the world. The questions which trouble people may be briefly formulated as - what they are, where they are and why they are. These questions are inseparable from the questions about the world itself, i.e. what it is, why it is, and how to understand its existence if we transcend it beyond the familiar and potentially understandable universe of time and space. The scope of these questions is very broad and includes the obvious problems of the everyday existence as well as the problems of the sense of life and the sense of the existence of the world. The former kind consists of the expectations of help in such practical mat- 
ters as preparing the offspring to cope with the hardships of life, to find their place in the society, to acquire the necessary manual and intellectual skills etc. Such attitude can be seen as a pragmatic view on education. The latter kind results from the realization that there are matters which exceed the practical targets of survival and that people are not satisfied with the popular conviction that the ultimate sense of existence is the existence itself. This type of approach will be referred to as a non-pragmatic view on education. It follows that in order to deal with such a broad range of problems and to account for both these kinds, it is necessary that the system of education should transcend the typical utilitarian ways of dealing with the learning processes and with the educational treatment.

The fundamental and unique source of all these questions and expectations is to be found in the capacity of the phenomenon of consciousness, which is practically realized by the selfconsciousness of every individual human being. The phenomenon of consciousness has emerged in the world in the course of its evolution which is characterized by its internal structural changes from simple forms to the more and more structurally complex forms of existence. However, the assumption that the universe evolves in an orderly manner, according to definite rules triggers a new troublesome question, namely, whether the phenomenon of consciousness actually concludes these evolutionary changes, or whether it takes a new direction of its further evolution. The vision of the possible direction may significantly influence the people's expectations of help from education in these matters.

Such confusing and conflicting questions and problems concern every individual person, which may be seen as a natural characteristic of people. However, everybody approaches them in a different way, with a different insight into them, comes to different conclusions and lives with different convictions about the sense of their lives, different knowledge of the world, different perception of the works of art and a different approach to the coexistence with other people, other families, 
tribes, nations or any other socially organized groups and communities. Practically speaking, everybody is in this respect different from everybody else in the world. These differences emerge because of the fact that the inborn capacity of selfconsciousness is flexible. It changes constantly because of a virtually infinite and unpredictable number of factors, e.g. the influence of parents, the innate predispositions and talents, the influence of the convictions and personalities of others, the social and political systems of organizing the coexistence of people, the massive propaganda of the rulers, the various kinds of formal and institutionalized forms of education, the influence of the environment and experience, the individually specific motivational drives etc. All these factors may be regarded as a great variety of the ways people acquire their education, which lasts from birth till the end of their lives.

The flexibility of the self-consciousness of every individual and its openness to broadening its scope make it a natural target of educational processes which in terms of practical realization through teaching concerns the behavioural patterns, mental processes and the inborn feeling of the universal moral principles of coexistence. The fact that everybody is different from everybody else with respect to the readiness for changes leads to the individual character of the educational treatment. Education in this view can be defined as educing the potential of every individual learner. Its main purpose is to exploit all the personal characteristics, talents and predispositions and, in this way, change the learner's knowledge of the world, explore the talents in order to develop the learner's creative powers, and develop the learner's sensitivity to the peaceful and harmonious coexistence with others.

Thus, in accord with these main purposes, the following educational domains may be distinguished: the domain of cognition, which is gaining the objective knowledge of the world, the domain of creation, which is developing the creative faculties of people and searching for their innate talents, and the educational domain of coexistence, which is involved with 
the universal moral principles. At the same time the aims of education are naturally involved with the mundane matters of everyday life, e.g. social relations, distribution of labour and all kinds of useful practical skills which are typically conducted by means of training and instruction and lead to definite vocations and specializations. It turns out that the expectations of help from education are tantamount to all queries which trouble people in their lives.

\section{The complexity of teaching points}

The great variety of the aims of the educational treatment may be ordered into hierarchies of their complexity of inclusion. For example, if the target is to teach how to use a computer to obtain some information, to write a text, to communicate etc. but the learner is not acquainted with the principles of working out a programme for any of these aims, the target is less complex than the one in which the main teaching point is working out programmes for any of these aims. Both these teaching points form a hierarchy of inclusion, i.e. anyone who learns how to work out a programme will, as a rule, be able to use it, but not everyone who is able to use it will be able to provide a programme for it. This kind of growing complexity may be established for any of the educational targets in any of the educational disciplines. For example, in language education everyone who has learnt how to construct written or spoken texts in a foreign language will be able to communicate, notwithstanding the circumstances of interaction, but the fact that a learner is able to send messages in the foreign language does not mean the ability to construct written or spoken texts in it. Consequently, the target of teaching how to construct texts is more complex than the one due to which the learner is only able to communicate, e.g. by means of body language, gestures, etc. In arithmetic the task to teach how to calculate the area of a circle is more complex than the task to teach multiplication etc. 
The degree of the complexity of the teaching point determines the degree to which the teaching procedure requires individualization. The more complex the task, the more individualized the procedure will have to be. For example, in the education of music the targets which concern the rhythmic differences between particular compositions are more complex than the points which concern the physical aspects of performance, e.g. the position of the hands of the learner over the keyboard of the piano. Although both these tasks are important for the performance, the tasks which concern the rhythmic problems are more complex because whenever we deal with them we also instruct and train the learner in the physical problems of the adequate position of the hands. However, we can imagine the possibility of training the learner in the physical intricacies without explaining the rhythmic problems. At the same time the explanation of the rhythmic problems requires to a greater degree the individual contact between the teacher and the learner because everyone is in a different way sensitive to the issues of rhythm. Such an individual contact between the teacher and the learner is not that essential in teaching the physical side of the performance because the physical constitution of the learners is basically similar and, therefore, allows for training and instruction in a group.

The correlation between the complexity of the teaching point and the degree of the individualization of the educational treatment of this point has important consequences for the kind of the whole educational system. Because of the great variety of the educational targets which are so different according to their degree of complexity, and because of the corresponding degree of the necessary individualization of the teaching procedures, the whole system cannot be limited to the pragmatic aims only, even though the procedures of the pragmatic aims are easier to perform - the tasks are simpler, do not require individualization, may be practiced in large groups and the teaching materials will be similar for all the 
learners in the group. Notwithstanding these convenient conditions there are serious disadvantages of such a system. First of all, the learners are likely to receive inadequate and crude answers to the serious questions about the nature of people and their sense of existence in the world. For example, in such serious matters the teaching points may be reduced to such mundane matters as popularity or entertainment, e.g. the learners may be trained how to give the impression of being spontaneous or how to become assertive to gain definite material advantages at all costs, or what to do in order to be admired etc.

A system of education which transcends the pragmatic targets in the domain of cognition appeals to the urge of learning the truth about the nature of people and to gain the objective knowledge of the world. In the domain of creation it appeals to the sensitivity and to the beauty of the works of art. In the domain of coexistence in a non-pragmatic system of education the learners ought to become aware of the fact that there are many other individuals around them who are equally selfconscious of their existence in the world and will attempt to search for the answers to the questions about the sense of their lives with a deeper insight into the nature of this existence. In the domain of cognition the learners will be expected to consider the knowledge of the world in a non-dogmatic way and the teaching points will deal with developing critical thinking. In the domain of creation the teaching points will focus on the ways to transcend the function of mere entertainment and prepare the learners to reach beyond the aesthetic pleasure of reception in their creative production.

\section{Learning motivation and a non-pragmatic view}

Education begins at birth and lasts for the whole life in connection with the learning processes. The educational treatment occurs either through intuitive self-education or in contact with the teacher. The learning processes correspond to the 
motivational drives to gain knowledge, to create artefacts and to behave according to moral principles. ${ }^{1}$ In the popular view the educational treatment is supposed to develop the intellectual capacity, manual skills and social awareness and behaviour. The usual agencies of education are explanation, instruction and training. The usual form of the teaching techniques and materials is a combination of these agencies.

There is a wildly accepted conviction that the basic function of education is to prepare the offspring to cope with matters of existence, so that they should manage to "get through life successfully" and to cooperate with others in this respect. In practice this function is realized by teaching how to fulfil the existential and psychosocial needs. The offspring is instructed and trained how to realize the needs which improve the quality of life such as comfort, health, entertainment, social position, power, prestige, accommodation, aesthetic pleasure, curiosity, satisfaction, relief of tension, excitement, security etc. The educational systems which care for all these needs are as a rule pragmatic in nature.

The psychosocial needs manifest various degrees of complexity which are reflected by the complexity of the teaching points. For instance, the needs of aesthetic pleasure or curiosity are more complex than the needs of security, comfort or excitement. The degree of complexity is marked by the inclusion of the less complex needs in the more complex ones. For example, whenever the need of curiosity is present, we may expect the needs of security or satisfaction, whereas the presence of the need of security does not imply the possible presence of the need of curiosity. In other words, one may be afraid of some danger which generates the need of security but not at all be interested in the origin of the danger, whereas the curiosity about its origin implies as a rule the need to be safe from it. Likewise, the need to have aesthetic pleasure of listening to a musical composition implies as a rule the need of satisfac-

1 For a more extensive discussion of the hierarchy of learning motivation see Wenzel (1994), Rychło (2008) and Aleksandrowska (2015). 
tion, whereas the need of satisfaction frequently does without any aesthetic pleasure.

From the organic point of view the pragmatic educational systems function as tools of the survival of the species and of the survival of particular individuals, social groups or communities. They perpetuate skills and behavioural patterns which prove successful in this respect and change them if they prove ineffective or harmful. This relation becomes different when the motivational drives of learning which are triggered by the existential and psychosocial needs transcend the requirements of the survival struggles. This new quality emerges thanks to the capacity of consciousness to activate the "higher mental processes" (Wenzel 2015) and make the individual open for the further development of the mind, notwithstanding the conditions and limitations imposed by the environment and by the physical and psychosocial needs. For example, the communication of the individuals becomes independent of time and space while sending and receiving messages. Also the message which is conveyed may be freed from the influence of the immediate circumstances of interaction, body language, degree of intimacy of the interlocutors, their intentions, expectations, age and a great number of other factors which influence the meaning of the message. The most spectacular manifestations of this capacity of the higher mental processes are the products of cognition and artistic creation which may be understood and interpreted by any number of successive generations irrespectively of the time and space between the authors and the addressee of these products.

The higher mental processes include a great number of characteristics which enable the motivational drives to transcend the practical needs. The most significant of them are generalizations, abstractions, notional comparisons and contrasts, criticism, logical speculation, notional clarification and reorganization in the mind, creative reconstruction of familiar ideas, creation of metaphors etc. These characteristics make it possible for the mind to become independent of the pragmatic 
aims of the motivational drives and to act subjectively with the use of free will. Thanks to these characteristics of the higher mental processes, learning becomes involved in the creation of ideas and artistic forms which have never existed before and which stimulate the growth of complexity of the educational treatment.

Education is inseparable from the learning processes. In other words, there is no education if the individual does not learn. The individual learns when there is a change. The change may be either of the behavioural kind or of the mental kind. The former kind of learning occurs when, thanks to the educational treatment, there is a change of the probability of response to external stimuli, the latter kind of learning occurs when there is a change of the cognitive structure of the learner's mind. ${ }^{2}$ The change of the probability of response to external stimuli characterizes behavioural patterns, whereas the change of the cognitive structure of the mind is characteristic of the development of the higher mental processes. Learning in the former case is definitely bound to the pragmatic targets of education. The latter kind of learning opens the possibility of transcending the pragmatic targets. This distinction is significant for the decisions concerning the educational treatment. The learning processes which involve the changes of the cognitive structure require principles and practical solutions adequate to the characteristics of the higher mental processes. It follows that such techniques as mechanical drilling or stimulus - response habit formation will not be effective if the targets are supposed to transcend the pragmatic level of education. In short, the study of the learning processes of pigeons, rats, dogs or monkeys is of no use for the educational treatment of the characteristics of the higher mental processes and consequently will not be effective in a non-pragmatic system of education.

2 These two types of learning, known as behavioural learning and mental learning respectively, have been extensively discussed by Kurcz (1992: 98170). 
Any kind of learning, whether characterized by the change of the behavioural patterns or by the change of the cognitive structure of the mind occurs thanks to the motivational drives of learning. These drives push and prod the individual to acquire the new habits or to reshuffle their conceptual apparatus by the acquisition of new concepts. The motivational drives of learning are natural, organic pressures which do not depend on volition, rational calculation, speculation, perspectives of material advantages or reasoning. All such causes which may set the motivational drives in motion may as well not activate them. For example, volition as a possible cause to trigger the motivation to learn the rules of a game for the sake of entertainment or aesthetic pleasure may possibly fail unless the willingness is supported by some kind of an organic drive, e.g. competitive drive, a psychosocial need to impress others, an urge to learn the truth at all costs, etc. The same problem concerns other manifestations of higher mental processes. No persuasion, reasoning, explanation, argumentation on logical grounds are likely to activate learning motivation unless they cooperate with the organic, natural pressures.

In the educational perspective the causes which may possibly activate the learning motivation necessary to change the cognitive structure are more complex than the causes which may activate the changes of the behavioural patterns. For example, curiosity, volition or reasoning are more complex than hunger, fear or sexual drives. Because of their complexity they are more difficult to be used for the educational treatment than such organic causes as hunger or fear. We deal here with a specific paradox. On the one hand, the more complex the causes are, the easier they cooperate with the higher mental processes. On the other hand, however, this cooperation becomes more difficult to achieve by the educational treatment. For example, the psychosocial need of aesthetic pleasure is very complex and easily cooperates with such higher mental processes as the creation of metaphors, symbolizing and generalization. However, the usual agencies of education such as 
explanation, instruction and training are not in a position to activate this cooperation. In other words, one cannot train or persuade the learner to gain aesthetic pleasure from a symphony or a poem. It follows that education at the level of the higher mental processes requires other, more complex agencies than the usual explanation, instruction or training, which are effective at the level of the behavioural patterns or habits.

The search for more complex educational agencies may be carried out on the basis of some outstanding products of the mind in the educational domains of cognition, creation and coexistence. All the evidenced instances of the outstanding achievements in these fields deal with the problems of the nature of existence, sense of life, the functions of knowledge and the artistic creation etc. in a larger context of causality and determinism than the direct cause-effect relations which are available for empirical observation, controlled experiments or statistics. Such products of the mind as great scientific works, philosophical debates, masterpieces of painting, sculpture, poetry, drama or music illustrate practically the potential ability of education to transcend the limitations of the practical, existential and psychosocial targets.

What has been possible to achieve by some outstanding products of the mind may become a general standard. The condition is that the principles of education should be elevated to the standards delimited by such products. The pragmatic targets, e.g. preparing the offspring to cope with matters of life should remain as an obvious and an indispensable part of education, but the dominant feature should be its foundation on the instances of the products of the mind which exceed these matters.

As it is, the general tendency seems to be directed towards the pragmatic systems of education in which the learning processes are limited to the realization of the psychosocial needs, whereas the sporadic great achievements of the mind are the products of some specially gifted individuals. The outstanding works are frequently created against the current educational 
principles, only thanks to the intuition of some philosophers, scientists, artists and teachers. This tendency is strongly supported by the focus of science and arts on technological inventions e.g. in the field of electronics due to which the learners make use of ready-made programmes for communication, information, entertainment, social behaviour and employment. In this way education loses its individual character, the teaching techniques and materials become uniform and consequently the development of the higher mental processes falls into stagnation and decline.

\section{Genuine interaction and the cognitive appeal of the teaching point}

Transcending the pragmatic targets of education involves gaining knowledge, artistic creation and moral behaviour. Gaining knowledge is basically motivated by the urge of searching for truth, artistic creation is motivated by the urge of achieving perfection in conveying the message and the beauty of its form, moral behaviour is basically motivated by the individual's conscience. The instances of transcending the pragmatic targets of education in these domains result from the cooperation of the organic motivational drives with the higher mental processes generated by consciousness. The agencies of the educational treatment, i.e. procedures, teaching materials, particular tasks and teaching points etc. should deal with both these factors to make it possible at all to transcend the pragmatic aims of education, i.e. they should deal with the development of the higher mental processes and with educing the potential of the organic motivational drives. The key issue in both of them is the character of the learning processes, which should focus on the change of the cognitive structure of the mind.

Establishing such a system seems to be a feasible and realistic task. The first step in the domain of cognition is to introduce the teaching targets developing critical thinking, argumentation and a constant improvement of explanations and 
speculations concerning the natural physical, chemical, biological and social phenomena grounded in empirical observation, data collection and statistics. The tools of these improvements are logical reasoning and the procedures of verification and falsification of explanatory theories. These procedures are dynamic and never final. The first step in the domain of creation is to leave the initiative of the educational treatment to the intuition and talents of the artists, i.e. poets, composers, painters etc. It is taken for granted that they would take care of the artistic workshop, and that they would educe the predispositions and talents of the learners. In the educational domain of coexistence the targets are universal moral principles and their place in the lives of the individuals. The educational treatment should deal with the social consent to such moral breaches as lying, stealing, killing etc. so as to prevent the communities, nations, tribes or families from wars, anarchy, unlawfulness, disintegration and all other kinds of social evils.

In all these domains the stress is on the individual relation between the learner and the teacher and the decisive role of the teacher in the choice of the teaching points and teaching materials according to the learner's predispositions, talents, personal characteristics and interests. In a way, the educational system which is based on transcending the utilitarian targets of learning deals with teaching in the strictest sense of this word. The teacher's main task is to explain the things to the learner and immediately make sure whether the learner grasps the subject matter of this explanation. It requires very close cooperation between the learner and the teacher as far as the teaching point is concerned. The teacher's talent, intuition and personal knowledge of the learner are essential to evoke the learner's willingness to further inquire about the subject matter of the teaching point without any special didactic techniques, tasks or activities which in the popular belief should motivate the learner. Instead, the motivating power should be found in the teaching point itself. 
Professionally, the teacher needs the skill of precise, clear and brief explanation of the teaching point. In the domains of cognition and coexistence the basic procedure is a discussion during which the teacher, together with the learner, approach the teaching point by means of the falsification of unreasonable explanations and searching for logical fallacies in them. It is the teacher's task to control the balance between the inductive and deductive learning processes. There are moments when the teacher turns into a philosopher who approaches the nature of such phenomena as space, time, and the innate universal moral principles. In the domain of creation the teaching points are connected with the artistic workshop of a given discipline and with examining the learner's predispositions to this discipline. It should be noted that in all these domains the whole attention of the educational treatment is devoted to the essence of the teaching point, not to the methods, techniques, activities or any other ways of its presentation.

The significance of the interaction between the learner and the teacher makes it necessary for the interaction to be genuine, i.e. it should focus on the content of the subject matter of learning. It is in this respect different from artificial interaction in which the attention of the educational treatment is directed towards the organization of the procedure according to the principles and prescriptions of a definite method elaborated on some theoretical grounds and expected to deal with the subject matter in a uniform way, notwithstanding the differences between the learners, their personalities, characters, interests, experience and the previously acquired knowledge of the subject matter.

The distinction between genuine and artificial interaction should not be understood in terms of priorities, preferences, being out of date or in vogue, or in any other sense "better" or "worse". The point rests in the consequences for the teaching materials and procedures. Genuine interaction favours teaching materials and procedures which lead to conscious acquisition of knowledge through the changes of the cognitive struc- 
ture, whereas artificial interaction promotes learning by habit formation and rote learning, ${ }^{3}$ which are effective in dealing with immediate practical targets, e.g. colloquial expressions in teaching a foreign language. In practice we may observe a characteristic conflict between these two ways of learning. Rote learning and behavioural learning require speed of reflection while responding to stimuli, whereas meaningful learning and mental learning depend very strongly on the teacher's explanations of the rules and principles of performance. The decisive factor of mental learning is grasping the point of the subject matter of teaching, whereas learning by habit formation aims at the ability of doing things with the acquired habits. Genuine interaction leads to the acquisition of knowledge thanks to the exchange of ideas between the teacher and the learner, whereas artificial interaction leads to establishing behavioural patterns through organized activities. In genuine interaction the learners are expected to say, to write or to do what they themselves want to express and the teacher becomes a genuine partner of the interaction who is really interested in what the learner has to say, to write or to do (Wenzel 2001: 47-108).

It follows that the genuine interaction between the learner and the teacher depends on the motivating power of the teaching points and the teaching materials They must be able to stir the eagerness to acquire knowledge and the urge for artistic creation to the extent at which the learners do not care about the hardships, lack of time or lack of the perspective of material advantages. The teaching materials and the teaching points which can engage the learning motivation in such a complex way manifest a phenomenon which may be defined as "having cognitive appeal" (Wenzel 2001: 47). This phenomenon could be contrasted with the popular epithet which refers to the

3 Another important distinction becomes relevant here, namely, into rote and meaningful learning; the main difference between them being the arbitrary relation (in rote) and nonarbitrary relation (in meaningful learning) of the acquired material to the cognitive structure (Ausubel 1968). 
physical aspect of life, namely "sex appeal". Both kinds of appeal cause unusual excitement. However, while sex appeal excites the biological processes and particular emotions, cognitive appeal refers to the capacity of teaching points and teaching materials to excite the mind. Instead of drawing the learner's attention to the entertaining aspect of the teaching procedures, they appeal to the imagination which has its source in abstractions, generalizations and notional intricacies. Every subject of the educational curriculum has its own, specific teaching points which have the potential of evoking cognitive appeal. It is the teacher who discovers which points could appeal to which learners and finds ways to match the targets with the higher mental processes. Such teaching points and teaching materials must excite the mind so as to make the learner willing to study things beyond the level of information, the expectation of the programme and the requirements of the tests.

The search for the cognitive appeal of the teaching points and the teaching materials depends on the intuition of the teacher. The teacher's activities may not be particularly spectacular or impressive and appear frequently in the form of casual remarks concerning the teaching point. For example, during a class of social studies the teacher wants to make sure that the learners understand the nature of political propagan$\mathrm{da}$ and intends to develop the skill of critical thinking to prevent its consequences in social life. The discussion may begin with asking the learners what they think about changing the name of the subject "social studies" into "education for democracy". At its face value such a term could be accepted as proper. However, in the discussion the teacher elicits from the learners the idea that essentially there is no difference between this concept and such notions as "education for socialism", "education for nationalism", or any other ideology in which the learners are indoctrinated. Then the learners are expected to reformulate this notion and with the help of the teacher come to the idea that education is for developing critical thinking so 
as to become immune to all kinds of demagoguery and propaganda.

If the learners show interest in the theme of political propaganda, which exceeds the usual requirements of the syllabus, the teacher may evoke the cognitive appeal by making allusions to other subjects of the curriculum, e.g. to political history or literature. For instance it may be a suggestion that we live with stereotyped interpretations which are imposed by the rulers. The teacher may mention the Shakespeare's drama Richard III according to which the king had murdered his nephew, committed several other crimes, and manifested cowardice by an attempt to escape from the battle at Bosworth on a horse for which he offered the whole kingdom. During the discussion the teacher may ask the learners, who ruled England at the time when Shakespeare wrote this play and elicit from them the observation that the black picture of the king could have been the effect of Tudor propaganda who deprived the York dynasty of power in an illegal way. If the learners start searching for information about those events of their own accord so as to learn the truth about them, and do it without the teacher's homework assignment, it is likely that this is the result of the cognitive appeal of the teaching point.

To further develop the theme of political propaganda the teacher may elicit from the learners their general knowledge about similar instances of political propaganda in other countries as well as in their native country, including modern times. Also, the theme may become a good starting point for a discussion on the relation between the propaganda of mass media and the political convictions of people. Such a discussion cannot be organized by means of teaching techniques, role-playing, entertaining activities etc. If, as a result of the discussion, the learners start asking critical questions, there is a good chance that the educational treatment and the learning process transcend the pragmatic level of direct advantages of education.

The teaching points and teaching materials of the domain of creation have their possible cognitive appeal when they 
evoke in the learners sensitivity to poetry, music, arts, drama, and any other discipline of artistic creation. The main problem of the educational treatment rests in the fact that the learners lose interest in the work of art when they are in any way forced to become acquainted with it. The development of sensitivity to anything disagrees on principle with telling someone to appreciate it. The following example illustrates a possibility which may or may not be effective, depending on the teacher's talent to engage with the learner in genuine interaction and individualization of the procedure. The teaching material is a fragment of a novel by John Galsworthy, The Forsyte Saga, Interlude The Indian Summer of a Forsyte.

The stable clock struck the quarter past. The dog Balthasar stretched and looked up at his master. The thistledown no longer moved. The dog placed his chin over the sunlit foot. It did not stir. The dog withdrew his chin quickly, rose, and leaped in old Jolyon's lap, looked in his face, whined; then, leaping down, sat on his haunches gazing up. And suddenly he uttered a long, long haul. But the thistledown was still as death, and the face of his master.

Summer - Summer - Summer

The soundless footsteps on the grass

(Galsworthy 1922: 437)

The teaching material functions here as an excuse for a discussion on its poetic character, in particular on its specific atmosphere. The learners are free to say whatever they feel that contributes to this atmosphere, without any instructions or suggestions of the teacher, who becomes a genuine participant of the discussion in which such elements may emerge as passing away, the dramatic parting of the dog with his master etc. The teacher may mention that the ability to observe such phenomena in nature and to combine them in a work of art signals that the person might have an artistic talent. The teacher may also suggest writing a composition in this vein. 
However, it would be definitely beyond the school requirements and there will be no evaluation and grading.

\section{Educing the potential of every individual learner}

It turns out that any system of education, no matter whether only pragmatic or transcending the practical targets, concentrates on two inseparable aspects, or, metaphorically speaking, two faces which cannot exist without each other. These two sides are - educational treatment which is mostly realized by teaching and the corresponding learning processes. Both of them are characterized by growing complexity of inclusion. On the teaching side the growth of complexity concerns adequate procedures, target tasks, teaching points, and teaching materials. A special position on the teaching side may be granted to the intuitive self-education of the learner, who, by definition must take over most of the teacher's decisions. On the learning side we deal with mental and behavioural changes which signal effective learning and natural, organic motivational drives which may or may not be evoked, and may or may not cause effective learning.

A system of education which transcends the pragmatic targets retains its characteristic features which are concerned with all its practical function, e.g. social behaviour, training the offspring, developing manual and intellectual skills, etc. However, there are some additional features which enable the learner to deal with such phenomena as the truth of the knowledge of the world and of the nature of people, the beauty of artistic creation and the innate feeling of the significance of moral behaviour. These phenomena generate questions which exceed the usual, practical functions of education and consequently require learning processes and motivational drives which function beyond the survival and psychosocial needs. The fundamental feature in this respect is the cooperation of the natural, organic motivational drives with the higher mental processes. The learner has to overcome the natural inclination 
to learn things with the perspective of direct practical advantages of the subject matter of learning and has to develop an urge to engage in the creation of metaphors and works of art, generalizations, critical thinking, elaborating explanatory theories and verify or falsify them. There are several conditions for the educational treatment to achieve this cooperation. Firstly, the interaction between the teacher and the learner must be genuine, not artificially organized, however interesting the organization might be. Secondly, the subject matter of learning must have cognitive appeal to the learner, i.e. it must excite the mind beyond the requirements of the programme and the teacher's expectations. Thirdly, the educational treatment must be individual because every learner has personal characteristics different from any other learner, and the teacher must be familiar with them. It might be tentatively stated that an educational system based on such non-pragmatic principles is in position to realize the classical postulate that education should be defined as educing the potential of every individual.

\section{References}

Aleksandrowska, Olga (2015). "On the motivation of adult learners in English language education”. In: Karolina Janczukowicz, Mikołaj Rychło (eds.). General Education and Language Teaching Methodology. The Gdańsk School of ELT. Frankfurt am Mein: Peter Lang, 77-94.

Ausubel, David Paul (1968). Educational Psychology. New York: Holt, Rinehart and Winston, Inc.

Galsworthy, John (1922). The Forsyte Saga. London: William Heineman Ltd.

Kurcz, Ida (1992). Pamięć, uczenie się, język. Warszawa: Wydawnictwo Naukowe PWN.

Rychło, Mikołaj (2008). The Educational Approach to Language Teaching. Warszawa: Wydawnictwo Naukowe PWN. 
Wenzel, Ryszard (1994). A General Theory of Language Education. Gdańsk: Wydawnictwo Uniwersytetu Gdańskiego.

Wenzel, Ryszard (2001). The Education of a Language Teacher. Gdańsk: Wydawnictwo Uniwersytetu Gdańskiego.

Wenzel, Ryszard (2015). "A direction of general education". In: Karolina Janczukowicz, Mikołaj Rychło (eds.). General Education and Language Teaching Methodology: The Gdańsk School of ELT. Frankfurt am Main: Peter Lang, 11-24.

Ryszard Wenzel Independent Scholar ORCID iD: 0000-0002-1257-105X 